\title{
ArgumentaCión, ARBITRAJE y ARBITRARIEDAD: LAS CONTRADICCIONES DEL TRIBUNAL CONSTITUCIONAL EN EL RECURSO DIRECTO DE NULIDAD CONTRA LAUDOS
}

[Argumentation, Arbitration and Arbitrariness:

The Contradictions of the Constitutional Tribunal in the Direct Recourse of Nullity Against Rulings]

\author{
Horacio Andaluz Vegacenteno* \\ Universidad Privada de Santa Cruz de la Sierra, Bolivia
}

\begin{abstract}
RESUMEN
Este artículo analiza una sentencia del Tribunal Constitucional de Bolivia desde el punto de vista de la argumentación de las decisiones judiciales. En ella, el Tribunal sostuvo que las pretensiones de nulidad contractual no eran materia arbitrable. A este artículo no le concierne el fondo de esta afirmación, sino las implicancias de la misma respecto a los anteriores precedentes del propio Tribunal Constitucional. En este sentido, el artículo concluye que, para dictar la sentencia en análisis, el Tribunal ha violado sus propios
\end{abstract}

\begin{abstract}
This article analyzes a ruling of the Bolivian Constitutional Tribunal from the point of view of the argumentation of the court rulings. In the ruling, the Tribunal stated that the request for contractual nullity was not a matter of arbitration. This article is not focused on the grounds of this assertion, but on its implications with respect to the precedents of same Constitutional Tribunal. In this regard, the article concludes that, to hand down the ruling in question, the Tribunal violated its own precedents for
\end{abstract}

RECIBIDO el 28 de octubre y ACEPTADo el 3 de diciembre de 2013

* Abogado, árbitro, profesor de la Universidad Privada de Santa Cruz de la Sierra, Bolivia, Máster en Derecho Internacional (Universidad Complutense de Madrid), antiguo alumno de la Academia de La Haya de Derecho Internacional, Master of LawsDerecho Constitucional y Filosofía del Derecho (Harvard Law School). Domicilio postal: Casilla 4710, Santa Cruz de la Sierra, Bolivia. Correo electrónico: handaluz@ post.harvard.edu 
precedentes respecto al recurso directo de nulidad (que es el recurso específico que produjo la sentencia en comento), respecto a la licitud de someter pretensiones de nulidad contractual a arbitramento y respecto a la producción judicial del derecho. Al tratarse de una sentencia contraria a sus propios precedentes, la misma es una sentencia arbitraria, lo que da título al presente artículo.

\section{Palabras Clave:}

Arbitraje - Motivación judicial - Orden público - Nulidad contractual the direct recourse of nullity (which is the specific recourse that resulted in said ruling) about the legality of submitting requests for contractual nullity to arbitration and regarding the judicial production of the law. Since this ruling is contrary to its own precedents, it is an arbitrary ruling, giving rise to this article.

\section{KEYWORDS}

Arbitration - Judicial motivationPublic order - Contractual nullity.

\section{INTRODUCCIÓN}

1. El título de este artículo se explica por sí mismo. Que una decisión judicial esté justificada (argumentada) significa que goza de cierto grado de corrección racional. A contrario, que materialmente carezca de justificación, o que la justificación que ostenta vaya en desacuerdo con la jurisprudencia ya afirmada, significa que es una decisión arbitraria. $Y$ esto es lo que se tiene acá: en su sentencia 2471/2012-RDN (22 de noviembre de 2012), el Tribunal Constitucional ha renegado de su propia jurisprudencia. No es que haya mutado sus líneas vigentes, sino que silenciosamente las ha rehuido. Al hacer esto, la arbitrariedad de su decisión quedó configurada. El título de este artículo viene de este hecho: contradecir la jurisprudencia propia sin modificarla expresamente es fallar arbitrariamente. Este es un estándar impuesto por el propio Tribunal Constitucional, que hace arbitraria a la sentencia en comento por tres razones: $i$ ) por contradecir la propia jurisprudencia constitucional sobre producción judicial del derecho, en lo que se refiere a rehuir los precedentes ya establecidos; $i$ i) por contradecir la jurisprudencia sobre el recurso directo de nulidad, en lo que se refiere a la jurisprudencia aplicable a sus presupuestos procesales; y iii) por contradecir la jurisprudencia sobre arbitraje, en lo que se refiere a la licitud de someter a arbitramento pretensiones de nulidad contractual.

2. En un Estado de Derecho toda decisión debe ser pasible de revisión judicial. Y los laudos no son la excepción. Negarlo supondría afirmar una contradicción, a saber, la validez de un producto jurídico producido extrasistémicamente. Tal planteamiento no tiene sostén. Si los laudos son derecho, 
entonces no pueden exorbitar el orden constitucional. Y si la Constitución es la fuente de validez del sistema jurídico, entonces los actos contrarios a ella merecen ser invalidados. Nada de esto es problema. El problema está en defender la Constitución violándola. Y eso es lo que ocurre cuando para su guarda se recurren a las vías procesales inconducentes a tal fin. Este es el problema acá. No se trata de enfrentar arbitraje y Constitución, sino de defender ambos. Y es así, porque sólo salvaguardada la Constitución puede salvaguardarse el régimen de libertades en el que entronca el arbitraje.

3. Hay críticas de dos tipos en este artículo. Las primeras se refieren a la falta de coherencia interna entre los propios argumentos de la sentencia 2471/2012-RDN. Puesto que no son el objeto mismo de este artículo, ellas son señaladas a tiempo de comentar descriptivamente dicha sentencia. La relevancia de hacerlas notar halla justificación en que las falacias argumentativas expresan una sutil forma de arbitrariedad judicial, que da un revestimiento de corrección racional a decisiones inconsistentes con el sistema jurídico. Bien por accidente o bien deliberadamente, tal sutileza es por igual peligrosa para el Estado de Derecho. Las segundas son las críticas fundadas en la jurisprudencia que la sentencia 2471/2012-RDN ha rehuido. Éstas son el objeto principal, como viene desde el título. Los párrafos tienen una sola numeración correlativa e independiente de los títulos en los que se divide el artículo. Con indiferencia de su extensión, cada párrafo se define por la unidad conceptual que conforma.

\section{LA SENTENCIA 2471/2012-RDN}

1. La sentencia $2471 / 2012-\mathrm{RDN}$ es producto de un recurso directo de nulidad presentado por la Procuraduría General del Estado contra un tribunal arbitral, por el pronunciamiento de un laudo. Dos fechas relevantes son las siguientes: el laudo era de 21 de enero de 2008; el recurso directo de nulidad de 3 de agosto de 2012. El laudo fue producido en un arbitraje entre una empresa pública y una sociedad anónima, que estaban vinculadas por dos actos jurídicos: un contrato de usufructo sobre un inmueble destinado a la prestación de un servicio público, de propiedad de la empresa pública, y un contrato de venta del mismo inmueble. A arbitramento se sometieron la pretensión de resolución de ambos contratos, más la pretensión accesoria de reparación de daños y perjuicios, por parte de la sociedad anónima (demandante principal), y la pretensión de nulidad de los contratos, y también la pretensión accesoria de reparación de daños y perjuicios, por parte de la empresa pública (demandante reconvencional). Llegado el laudo, éste declaró: $i$ ) resuelto el contrato de usufructo; ii) improcedente la pretensión de resolución del contrato de venta; iii) nulo el contrato de venta con efec- 
tos retroactivos (i.e. devolución del precio); y iv) improbada la nulidad del contrato de usufructo.

2. Contra este laudo se dirigió el recurso directo de nulidad, por las dos razones siguientes, dependiente la segunda de la primera.

a) De un lado, la Procuraduría General del Estado argumenta que el laudo contrariaría el artículo 546 del Código Civil, que dice: "la nulidad y la anulabilidad de un contrato deben ser pronunciadas judicialmente". De aquí concluye que el tribunal arbitral habría ejercido impropiamente las competencias reservadas a la jurisdicción ordinaria, por el hecho de haberse pronunciado en lo sustantivo sobre las acciones de nulidad llevadas al arbitraje. En su respaldo, se apoya en decisiones previas del Tribunal Constitucional y de la Corte Suprema de Justicia. Del primero, apela a la sentencia 209/2007-RAC (29 de marzo), porque entiende que en ella la jurisdicción constitucional ya habría dicho que la nulidad contractual era materia exclusiva de la jurisdicción ordinaria. Y apela también a la sentencia 49/2004-RDN ( 18 de mayo), porque entiende que el Tribunal habría ido más allá inclusive, reservando la nulidad contractual a la competencia exclusiva de la Corte Suprema. De la segunda, apela al AS-Sala Plena 60/2003 (29 de agosto), porque entiende que la Corte Suprema habría hecho suya la jurisprudencia constitucional referida. Hasta aquí la primera razón invocada.

b) De otro lado, la Procuraduría argumenta que el laudo se habría pronunciado sobre materia no arbitrable, por tres razones: $i$ ) El objeto del contrato de venta era la traslación del dominio propietario de un inmueble que requeriría de autorización legislativa para su venta. De aquí deriva que dicho inmueble no era disponible, de lo que concluye que el laudo se habría pronunciado sobre derechos indisponibles. ii) El contrato de venta no podía ser materia arbitrable, porque entiende que se refería a derechos que afectaban al orden público. Por todo argumento, se limita a sostener que la sanción de nulidad es un asunto que concierne a tal orden; iii) El tribunal arbitral habría decidido sobre un asunto concerniente a las funciones del Estado como persona de derecho público, porque al decidirse la nulidad de la venta habría desconocido el poder de imperio de éste. Hasta aquí los argumentos de la Procuraduría, tal como fueron tomados por la sentencia 2471/2012-RDN (párrafo I.1.1).

3. Dos comentarios al respecto.

a) Lastima cuestiones de la más básica juridicidad el hecho que la misma parte que demandó la nulidad de los contratos sea la que luego denuncie la nulidad del laudo por pronunciarse sobre las pretensiones que ella misma llevó al arbitraje. La aceptación de las reglas a conveniencia no es plausible en un Estado de Derecho. Para situaciones así, el derecho anglo-americano conoce el "estoppel”, que impide que una parte haga una alegación contraria 
al sentido objetivo de su anterior conducta. A diferencia de la doctrina de los actos propios desarrollada por la tradición civil, el "estoppel” no crea, modifica ni extingue un acto jurídico: su eficacia es procesal, actúa como un medio de defensa que hace inadmisible en juicio la alegación contraria al acto propio. Pero, al igual que la doctrina de los actos propios, el estoppel es también una derivación de la regla "venire contra factum propium non valet" ("no es lícito actuar en contra de los propios actos")1. Por tanto, en

${ }^{1}$ En esta regla también toma fundamento la doctrina constitucional de los actos consentidos. Pero esta doctrina no es un "estoppel", porque no opera impidiendo procesalmente una pretensión, sino extinguiendo el derecho reclamado. Véase a continuación el razonamiento del Tribunal Constitucional y nótese el contenido sustantivo de la doctrina en cuestión, que atribuye su fundamento a la dejación de un derecho: "[la doctrina de los actos consentidos] tiene su fundamento en el respeto al libre desarrollo de la personalidad, lo que significa que toda persona puede hacer lo que desee en su vida y con su vida sin que la Sociedad o el Estado puedan realizar intromisiones indebidas en dicha vida privada; pues se entiende que toda persona tiene la absoluta libertad de ejercer sus derechos de la forma que más convenga a sus intereses, con la sola condición de no lesionar el interés colectivo o los derechos de las demás personas, por lo mismo, frente a una eventual lesión o restricción de su derecho fundamental o garantía constitucional la persona tiene la libertad de definir la acción a seguir frente a dicha situación, ya sea reclamando frente al hecho ilegal, planteando las acciones pertinentes o, en su caso, de consentir el hecho o llegar a un acuerdo con la persona o autoridad que afecta su derecho, por considerar que esa afección no es grave y no justifica la iniciación de las acciones legales correspondientes" (sentencia 1890/2012-AAC, 12 de octubre, párrafo III.2.2). Ahora compárese este razonamiento con el siguiente, propio del "estoppel": "Es una regla jurídica bien establecida que el error no puede ser alegado como vicio del consentimiento si quien consintió contribuyó con su propia conducta al error o pudo haberlo evitado o, si las circunstancias lo permitían, pudo haberse enterado de ese posible error" (Corte Internacional de Justicia, asunto "Templo de Preah Vihear, Camboya c. Tailandia”, de 1962). Compárese ambos razonamientos y se notará que el segundo no tiene eficacia sustantiva. No sostiene la extinción de un derecho, sino la imposibilidad de reclamar por un derecho a causa de una conducta propia. Se trata de un medio de defensa procesal, mientras que el acto propio de la tradición latina opera como un medio de defensa material. Una ventaja del razonamiento procesal del "estoppel" es que no genera la inexacta imagen de estar convalidando la validez de un acto viciado a través del consentimiento tácito, que en algunas ocasiones genera el razonamiento sustantivo de la doctrina de los actos propios. Ejemplo de esto es la sentencia 1/2013-L ( 4 de enero), en la que el Tribunal Constitucional afirma que la doctrina de los actos consentidos no se aplica a las nulidades absolutas, definiendo a éstas como aquellas producto de la violación a normas imperativas de procedimiento (párrafo III.4). El razonamiento subyacente en esta afirmación es la eficacia sustantiva de los actos propios. Si por el acto propio se puede crear, modificar o extinguir un derecho, entonces la doctrina sólo es aplicable a los actos que caen bajo el poder de disposición de los particulares. En consecuencia, como las normas procesales no son de libre disponibilidad, el consentimiento tácito manifestado en la inacción de una parte 
la medida que es una consecuencia de racionalidad práctica derivada de la buena fe, todo sistema jurídico que reconozca a la buena fe como principio podrá jurisprudencialmente desarrollar el "estoppel" como una aplicación del mismo ${ }^{2}$. Hasta aquí el primer comentario.

b) El segundo: la jurisprudencia alegada no es precedente constitucional a favor de que la declaratoria de nulidad de los actos jurídicos sea materia reservada excluyentemente a favor de la jurisdicción ordinaria, por lo siguiente: i) En la sentencia 209/2007-RAC el Tribunal Constitucional decidió una acción de amparo demandada por la misma sociedad anónima que luego sería parte en el arbitraje. Los hechos: funcionarios del Ministerio Público, auxiliados por oficiales de la Policía boliviana y del Ejército, tomaron el control efectivo del mismo inmueble que había sido materia de usufructo y de venta entre esta sociedad anónima y la empresa pública (la misma empresa que luego sería parte en el arbitraje). Luego entregaron el inmueble a la empresa pública, destituyeron al administrador de la sociedad anónima y designaron a un interventor. $Y$ todo esto sin orden judicial alguna. Como justificativo a tiempo del amparo, los recurridos alegaron que la venta del inmueble en cuestión era ilegal. Y es acá que el Tribunal sostuvo que la declaratoria de nulidad no correspondía a la jurisdicción constitucional, sino a la jurisdicción ordinaria (párrafo III.2). En el contexto, lo que el Tribunal está diciendo es que no le compete al Ministerio Público decidir sobre la validez de los actos jurídicos. De ahí que hubiese concluido que la actuación de los funcionarios

no puede extinguir su derecho. Hasta aquí claro. Pero, bien visto, la inacción de la parte no habrá extinguido su derecho, pero sí causado que, por efecto de la preclusión, el acto procesal vulneratorio de las normas de procedimiento ya no pueda ser revisado. Vale decir, el resultado es el mismo: la imposibilidad de atacar el acto y su firmeza por dicho motivo. La diferencia estriba en el razonamiento que lleva a esa conclusión: si se trabaja con el "estoppel", será esta doctrina por sí sola la que sirva de sustento, porque como no tiene eficacia sustantiva, su aplicación no supone para el pensamiento jurídico la inexactitud de aparecer imponiendo como condición convalidatoria de validez un presupuesto no contemplado para la formación del acto. En cambio, si se trabaja con la doctrina de los actos propios, su aplicación llevaría al absurdo de postular que un acto que no requiere para su formación el consentimiento expreso de una parte, puede ser convalidado por su consentimiento tácito. Como tal conclusión no puede sostenerse, el pensamiento jurídico debe rechazarla, como lo ha hecho la ST sentencia C 1/2013-L. Y en su auxilio debe recurrirse a un instrumento netamente procesal: el de la preclusión, que por igual impide atacar el acto por haber vencido la oportunidad para hacerlo. Si de dos vías una es la más corta, pareciera que el pensamiento jurídico debiera decantarse por ella, como exigencia de limpieza intelectiva para abordar el mismo objeto.

${ }^{2}$ Por lo demás, tampoco significaría la introducción ex novo de un contenido en el sistema jurídico, ya que en el ordenamiento nacional hay antecedentes de legislativos de "estoppel", como la prohibición a los cónyuges de fundar la acción de divorcio en su propia falta (artículo 134 del Código de Familia). 
de esta dependencia constituyó una vía de hecho atentatoria de los derechos constitucionales de la sociedad anónima (párrafo III.3). Pero el Tribunal no dijo que la declaratoria de nulidad no pudiese ser objeto de arbitramento, porque la pretensión específica materia de amparo versaba sobre la actuación de los funcionarios del Ministerio Público, no sobre la competencia de jurisdicción primaria alguna. ii) La sentencia 49/2004-RDN y el AS-Sala Plena 60/2003 fueron pronunciados como incidencias en un asunto por cuya emergencia se pronunciaron en total cinco decisiones judiciales: tres del Tribunal Constitucional y dos de la Corte Suprema. El caso: el Ministerio de Defensa demandó en la Corte Suprema la nulidad de un contrato entre dicho despacho y una empresa privada. La empresa privada excepcionó la competencia de la Corte, alegando la existencia de una cláusula arbitral. Pero la Corte razonó que la declaratoria de nulidad era asunto propio de la jurisdicción ordinaria y que, tratándose de un contrato con el Poder Ejecutivo, correspondía a esa instancia la sede. Para lo primero se sustentó en el artículo 546 del Código Civil y para lo segundo en los artículos 775 a 777 del Código de Procedimiento Civil. Este fue el AS-Sala Plena 60/2003 (29 de agosto). En vía paralela, el Ministerio de Defensa demandó en acción de amparo al tribunal arbitral que se había formado a partir de la demanda presentada por la empresa privada. Como la Ley de arbitraje y conciliación dice que se pueden seguir con las actuaciones arbitrales "mientras la excepción [de incompetencia] esté en trámite ante el juez" (artículo 12.IV), el Tribunal Constitucional decidió que el tribunal arbitral era competente en tanto no se pronunciase la Corte Suprema (sentencia 1424/2003-RAC, 29 de septiembre). Luego el Ministerio de Defensa demandó en recurso directo de nulidad las actuaciones arbitrales producidas después de la declaratoria de competencia de la Corte Suprema. Como para ese momento ya se sabía del AS-Sala Plena 60/2003, el Tribunal Constitucional declaró nulas las actuaciones demandadas (sentencia 49/2004-RDN, 18 de mayo). Ya afirmada su competencia, la Corte Suprema se pronunció sobre el fondo del asunto, declarando la nulidad del contrato en cuestión (AS-Sala Plena 148/2004, 19 de noviembre). Para terminar, la empresa privada demandó en amparo constitucional este último auto supremo. Pero el Tribunal encontró que en la resolución del fondo del asunto no se habían vulnerado sus derechos constitucionales. Y, sobre el asunto de la competencia, encontró que había ya decisiones firmes que lo hacían irrevisable (sentencia 631/2006-RAC, 30 de junio). Hasta aquí el caso. Pero ninguna de estas sentencias es precedente constitucional en sentido que la declaratoria de nulidad sea competencia reservada excluyentemente a favor de la jurisdicción ordinaria, por dos razones. $i)$ Porque jamás se controvirtió en la jurisdicción constitucional que la declaratoria de nulidad pudiese ser materia de arbitramento (la participación 
del Tribunal Constitucional no fue para pronunciarse sobre la competencia de una jurisdicción primaria). ii) Porque la única decisión que afirma que la declaratoria de nulidad de los actos jurídicos es competencia de la jurisdicción ordinaria (el AS-Sala Plena 60/2003) es en sí misma una decisión arbitraria, porque, igual que la sentencia 2471/2012-RDN, es una decisión que rehuyó la aplicación de la jurisprudencia constitucional vigente a tiempo de su dictado, como se verá en el párrafo 29 (queda al margen el hecho obvio que un fallo de la jurisdicción ordinaria no es precedente producido por la jurisdicción constitucional).

4. Llegado el tiempo de resolver, el Tribunal Constitucional comenzó elaborando sobre cuatro cuestiones de naturaleza procesal involucradas en el caso.

a) Abrió su motivación refiriéndose a la naturaleza jurídica del recurso directo de nulidad. $\mathrm{Al}$ respecto, dijo que el mismo tutelaba la garantía de competencia y que sancionaba con su nulidad a los actos producidos ultra vires. Su retórica en este aspecto fue general e insuficiente. General, porque se limitó a explicitar el texto del artículo 122 de la Constitución, que dice que los actos producidos sin competencia son nulos. E insuficiente, porque no elaboró respecto al carácter directo del recurso en cuestión, que es precisamente lo que define su entidad jurídica procesal. Lo único que podría asumirse como una motivación referente al caso concreto es la cita subrayada que hizo del artículo 157 de la Ley del Tribunal Constitucional Plurinacional, en lo referido a que el recurso procede contra los actos "de quien ejerza jurisdicción o potestad que no emane de la ley" (párrafo III.1). Pero esta inferencia dista mucho de satisfacer la obligación de explicar los fundamentos del caso en análisis, que corresponde a todo tribunal.

b) Luego el Tribunal justificó la legitimación de la Procuraduría General del Estado para accionar en este caso. Su explicación fue textualista: ya que el artículo 231 de la Constitución dice que la Procuraduría puede actuar en defensa de los intereses del Estado como sujeto procesal de pleno derecho en todas las acciones judiciales y administrativas, interponiendo recursos ordinarios y acciones de defensa, entonces puede, sin necesidad de decir más, accionar en este caso (párrafo III.2.1).

c) Del hecho que la demanda estuviese dirigida contra el tribunal arbitral, el Tribunal razonó que el recurso directo de nulidad también es aplicable a los particulares que ejerzan una función de relevancia pública, porque "el ejercicio competencial o jurisdiccional puede en su caso ser de relevancia bajo la perspectiva del orden público, como sucede en el caso de autos" (párrafo III.2.2). La cita adelanta un criterio de excepción: no está definiendo el objeto de la pretensión del recurso directo de nulidad a partir de la garantía de competencia (i.e. es materia del recurso la violación a dicha garantía), sino a partir de la 
importancia ("relevancia") de la competencia ejercida. Dos cosas al respecto: si lo que define al objeto de la pretensión del recurso directo de nulidad es la relevancia de la competencia comprometida, entonces $i$ ) su naturaleza jurídica es distinta a la que refirió el Tribunal en la misma sentencia; y $i i)$ es reprochable que el Tribunal no se detuviese a explicar lo que hace relevante a una competencia como para que su transgresión califique como objeto del recurso directo de nulidad: desde el punto de vista de la justificación de las decisiones judiciales, motivar respecto del objeto de la pretensión parece una exigencia impuesta por el puro sentido común, porque de la claridad jurisprudencial de su definición depende el destino de la acción.

d) Finalmente, sobre el plazo de presentación del recurso directo de nulidad, se construyó el siguiente argumento: $i$ ) el plazo aplicable a esta acción en particular estaba reglado por la Ley del Tribunal Constitucional Plurinacional y era de seis meses a partir de la notificación o de la ejecución del acto denunciado (artículo 159); ii) aunque entre la fecha del laudo (21 de enero de 2008) y la fecha del recurso (3 de agosto de 2012) hay más de seis meses, el ejercicio de la acción no había caducado aún, porque la Procuraduría General del Estado conoció recién del laudo el 13 de julio de 2012, cuando le fue comunicado por el Ministerio de Obras Públicas, Servicios y Vivienda (párrafo III.2.3). De momento lo siguiente: si el plazo comenzaba a correr a partir de que la Procuraduría tomase conocimiento, entonces su participación en el caso no sería en representación del Estado, sino a nombre propio. Para que los fundamentos 2 y 4 guardasen coherencia entre sí, o bien la Procuraduría actuaba como representante del Estado y el plazo estaba caducado, o bien actuaba a nombre propio y el plazo estaba vigente, pero no las dos cosas a la vez.

5. Para llegar a que la declaratoria de nulidad del contrato de venta fue una actuación arbitral contraria al orden público por arrogarse competencias reservadas a la jurisdicción ordinaria, el Tribunal dio dos argumentos.

a) Comenzó por lo obvio: el carácter arbitrable de una controversia (párrafo III.3). Para esto, se sirvió primero de los artículos 3, 6 y 63.I de la Ley de arbitraje y conciliación, para concluir en la imposibilidad de arbitrar controversias sobre: $i$ ) "materias expresamente excluidas"; $i$ i) "derechos sobre los cuales no se puede pactar libremente"; y iii) "indisponibilidad de aspectos vinculados al orden público que sólo pueden ser dilucidados por la jurisdicción estatal" (arbitrabilidad objetiva, párrafo III.3.a).Esta clasificación es redundante. Lo es, porque las "materias expresamente excluidas" son aquellas que "no se pueden pactar libremente" y que "sólo pueden ser dilucidadas por la jurisdicción estatal”, como queda de la literalidad de los artículos 3 y 6 de la Ley de arbitraje y conciliación. Para no repetirse doblemente, hubiese bastado con referirse al género (i.e. "materias expresamente excluidas"), sin escindirlo innecesariamente en sus propias especies. Hecho esto, el Tribunal 
tomó el artículo 4 de la Ley de arbitraje y conciliación para decir que el Estado puede someter sus controversias sobre derechos disponibles a arbitramento (arbitrabilidad subjetiva, párrafo III.3.b).

b) Dicho esto, siguió refiriéndose al régimen de nulidad de los contratos. Sobre éste, dijo que los vicios de nulidad se producen cuando se transgreden normas imperativas, que como tales suponen una limitación a la libre autonomía de la voluntad. Hasta aquí bien. Pero luego tornó en equivalentes las normas imperativas, cuya violación produce un vicio de nulidad, con el orden público. Y de esto concluyó ("por lo cual”, dijo, párrafo III.4) que la declaratoria de nulidad correspondía únicamente a la jurisdicción ordinaria, citando al efecto el artículo 546 del Código Civil. Hasta aquí dos cosas: i) la equivalencia entre orden público y normas imperativas revela que el Tribunal desconoce la distinción entre orden público interno y orden público internacional; y ii) que el régimen de nulidades nazca de normas imperativas no quiere decir, por vía de deducción, que su declaratoria esté reservada al Estado: todo lo que quiere decir es que dicho régimen no admite excepción de pacto en contrario y que, por consecuencia, quien conozca de una acción de nulidad está obligado a aplicar tales normas imperativas. La competencia para declarar la nulidad de un acto jurídico es un asunto de derecho positivo y es con esto que tiene que lidiar el Tribunal, a partir del artículo 32.II de la Ley de arbitraje y conciliación, que dice: "La decisión arbitral que declare la nulidad de un contrato no determinará de modo necesario la nulidad del convenio arbitral". Enfrentado con esta norma, el Tribunal Constitucional dice que ella "permitiría entrever" (párrafo III.4) que la declaratoria de nulidad puede ser materia de arbitramento, pero que una interpretación sistemática no avala esto. Según tal interpretación: i) como el Código Civil dice que la nulidad sólo puede ser declarada judicialmente, entonces nadie más que los jueces puede declararla; y ii) como la anterior afirmación vacía de contenido al artículo 32.II de la Ley de arbitraje y conciliación, el Tribunal dice que ese artículo se refiere al régimen de nulidades pactadas contractualmente. Sobre esto último: si en el mismo párrafo III.4 el propio Tribunal está diciendo que el régimen de nulidades nace de normas imperativas y las casa con el orden público, entonces según su propio razonamiento no puede haber un régimen de nulidades que nazca de la autonomía de la voluntad de las partes contratantes, como de hecho no lo hay, porque la declaratoria de nulidad importa la pérdida de validez y sólo puede condicionar la validez una fuente con anterioridad lógica-normativa a la fuente cuya validez deriva de ella; de ahí que el régimen de nulidades venga de la misma fuente que condiciona la validez de los contratos, que para el caso es el Código Civil.

6. Así fue como se llegó a la declaratoria de nulidad del laudo, pero con una disidencia. Al votar, la magistrada Chanéz Chire disintió: i) del plazo 
de presentación del recurso; y ii) de la legitimación de la Procuraduría General del Estado para accionar. Aunque aparentan ser dos fundamentos independientes, se trata en puridad de uno solo, el primero, respecto del cual el segundo es un argumento de consecuencia, como lo advierte la propia disidencia (párrafo I). i) Del plazo, da por bien hecho que la mayoría lo hubiese regido por la Ley del Tribunal Constitucional Plurinacional, pero disiente de su cómputo. A su juicio, los seis meses que dicha Ley establece para el ejercicio de la acción habrían ya caducado a tiempo del recurso directo de nulidad (párrafo II.3). ii) De la legitimación de la Procuraduría, no controvierte su competencia para representar al Estado, pero sí que la haya ejercido fuera de plazo (párrafo II.4). Aplicados estos argumentos al caso, concluye que, para el tiempo de presentación del recurso directo de nulidad, el laudo arbitral ya gozaba de la inmutabilidad propia de las decisiones sobre las que recae la calidad de cosa juzgada. Por consiguiente, la Procuraduría no podía accionar contra una decisión que el ordenamiento procesal había declarado firme y definitiva. Y ya que se dio lugar al recurso a pesar de haber caducado el derecho para su accionamiento, dice que: $i$ ) le es preocupante los efectos que pueda tener una "interpretación lesiva para la estabilidad del ordenamiento jurídico"; y ii) que la interpretación de la mayoría "corre el riesgo de abrir un precedente incierto, que origine un escenario de estado de indefensión no querido por el orden constitucional" (párrafo II.5). Los dos son temores fundados.

\section{ARgUMENTACIÓN Y ARBITRARIEDAD}

1. La aceptación de una decisión es un pronunciamiento sobre su corrección racional. Hay corrección racional cuando las decisiones son justificables por su universalidad, su coherencia y su consecuencia con los valores del sistema. La justificación de las decisiones judiciales es una exigencia del Estado de Derecho, no un elemento lógico del sistema jurídico. Sólo en el Estado de Derecho se considera que una decisión no está suficientemente justificada por el solo hecho de haber sido dictada por una autoridad competente (determinismo metodológico). Aquí, a la estabilidad formal de las decisiones, debe agregársele la corrección racional de su justificación. Fundamentar una decisión judicial no es exponerla (labor descriptiva), sino justificarla. Dar razones que sostengan la corrección racional de la decisión adoptada. La justificación conlleva formular juicios evaluativos (formales o materiales) sobre el derecho y los hechos del caso. De esto se desprende, como regla natural, que la argumentación será más compleja cuanto más complejos sean los casos. Tratándose de la justicia constitucional, la labor argumentativa arrastra las complejidades propias de; i) resolver en el marco 
de la indeterminación característica de las Constituciones; y ii) decidir autoritativamente sobre el significado jurídico de la Constitución. Con esto, en cada decisión constitucional los tribunales tienen en sus manos todo el Estado de Derecho.

2. La justificación de las decisiones significa control democrático sobre los tribunales por dos razones.

a) Porque es la precondición de toda segunda instancia y de toda vía recursiva. Aquí los afectados accionan fundándose en la justificación de la decisión objetada. Piden que un órgano autorizado para enjuiciar los actos de otro se pronuncie al respecto. Se trata del sistema de frenos y contrapesos aplicado intra organum y promovido como contenido de una pretensión procesal. Constituye el derecho a obtener una sentencia fundada, que nace de la tutela judicial efectiva y del debido proceso (artículo 115 de la Constitución). Ya estaba suficientemente afirmado en la jurisprudencia $i$ ) la relación entre motivación, debido proceso y tutela judicial efectiva; $i i$ ) que el cumplimiento de la exigencia de motivar se medía por su cometido constitucionalmente asignado de proporcionar conocimiento material efectivo sobre las razones de la decisión; y iii) que la carencia de motivación significaba comisión de acto arbitrario (por todas (sentencia 1163/2006-RAC, 20 de noviembre, párrafo III.2; y sentencia 937/2006-RAC, 25 de septiembre, párrafo III.3.1). Esto no ha variado (por todas, la sentencia 2212/2010AAC, 19 de noviembre, párrafo III.3; y sentencia 275/2012-AAC, 4 de junio, párrafo III.2.1). La reafirmación de la jurisprudencia ha llevado: $i$ ) a enfatizar la mayor importancia que tiene la motivación cuando se está ante un tribunal de cierre (sentencia 2210/2012-AAC, 8 de noviembre, párrafo III.1) y ii) a determinar el contenido esencial del derecho a obtener una sentencia fundada a partir del telos propio de la justificación de las decisiones en el Estado de Derecho. Con esto, la motivación ha adquirido corporeidad propia, que redunda en su garantía. Como su autonomía normativa viene de los fines que debe cumplir, para el respeto de su contenido esencial las decisiones deben: $i$ ) expresar el sometimiento manifiesto a la Constitución y al derecho ordinario en general; ii) convencer de que la decisión es expresión de justicia, razonabilidad y congruencia con lo pedido, y no fruto de la arbitrariedad; iii) garantizar la posibilidad de control de la decisión por los medios de impugnación respectivos; $\mathrm{y} i v$ ) permitir el control de democrático de los tribunales (sentencia 2221/2012-AAC, 8 de noviembre, párrafo III.1).

b) Porque es la precondición para la creación judicial del derecho. Un precedente se afirma por la fuerza de su justificación y se lo cambia cuando la fuerza de otra justificación articula mejor en el sistema jurídico. Acá la justificación de las decisiones judiciales es una exigencia que viene del derecho a la igualdad ante la ley (artículos 8.II y 14.III) y de la garantía de seguridad 
jurídica (artículo 178.I). En un inicio el Tribunal Constitucional no tuvo esto en claro. Su argumento para fundar la obligatoriedad de sus precedentes tomaba apoyatura en su Ley de organización (sentencia 1781/2004-RAC, 16 de noviembre, párrafo III.1), sin advertir lo denigrante de tal razonamiento para la supremacía constitucional. Si para ser vinculantes los precedentes necesitan de una ley, entonces sería la ley la fuente suprema del ordenamiento y no la Constitución. Pero esto ha sido enmendado por el propio Tribunal. En la sentencia 846/2012-AAC (20 de agosto, párrafo III.3) el Tribunal $i$ ) afirmó el valor de la jurisprudencia como fuente directa del derecho; ii) fundó su fuerza vinculante en la igualdad y en la seguridad jurídica; iii) reconoció la importancia de los precedentes para la unidad y coherencia del ordenamiento; $i v$ ) recordó que los cambios jurisprudenciales deben estar fundados en interpretaciones que acomoden mejor con la Constitución; $v$ ) respecto al cambio de precedentes, sostuvo que puede hacerse con la "motivación suficiente" (i.e. no rehuirlos silenciosamente, párrafo III.3.1.d); vi) diferenció entre precedente y dicta; vii) afirmó la aplicación inmediata en el tiempo de la jurisprudencia; viii) introdujo el concepto de prospective overrule; y $i x)$ hizo pedagogía acerca de la aplicación e invocación de sus precedentes.

3. La argumentación de una decisión exige una rigurosa economía del razonamiento jurídico, que por criterio de razón suficiente evite cuestiones impertinentes al asunto en cuestión. La adecuada justificación de las decisiones judiciales comienza por distinguir entre casos fáciles y difíciles.

a) Son fáciles los casos cuyas premisas normativas y fácticas no son controversiales. Puesto que sus premisas son convencionalmente aceptadas, se producen conclusiones racionalmente aceptables sin necesidad de mayor esfuerzo argumentativo. Por esto, el razonamiento deductivo es suficiente para justificar la decisión. Esta es una justificación formal o de primer nivel. Aquí el silogismo de Beccaria basta ${ }^{3}$.

b) Son difíciles los casos cuyas premisas no son convencionalmente aceptadas. i) Tratándose de sus premisas normativas, esto puede deberse a problemas de relevancia o de interpretación. Son problemas de relevancia las dudas sobre la determinación de la norma aplicable o sobre su propia existencia. Los problemas de interpretación suponen dudas sobre el significado jurídico de la norma aplicable. ii) Tratándose de las premisas fácticas, que no sean convencionalmente aceptadas puede deberse a problemas de prueba o de calificación. Se llaman problemas de prueba a las dudas sobre la existencia de los hechos requeridos para hacer operativa la hipótesis de la

${ }^{3}$ Refiriéndose al Derecho penal, decía BecCaria, César; De los delitos y de laspenas (traducción al castellano, Madrid, Aguilar, 1974, p. 76: "En todo delito debe hacerse por el juez un silogismo perfecto: la premisa mayor debe ser la ley general; la menor, la acción conforme o no con la ley; la consecuencia, la libertad o la pena". 
norma. Y son problemas de calificación las dudas sobre la determinación del significado jurídico de un hecho probado.

4. Desde el punto de vista de la argumentación, el razonamiento deductivo es insuficiente para justificar la decisión de un caso difícil. Aquí, a la lógica formal (justificación de primer nivel), debe sumársele criterios de razonabilidad (justificaciones de segundo nivel). De esta manera, cada premisa problemática debe justificarse en criterios que sostengan la corrección racional de la decisión tomada. Hecho esto, la justificación formal puede ejecutarse. En este sentido, el razonamiento deductivo no sólo describe los casos fáciles, sino también los difíciles. No hay caso en que la decisión judicial, desde que es aplicación del derecho, no vaya de una norma general a una particular. El problema está en determinar las premisas del silogismo. Una vez justificadas, la decisión podrá describirse como un proceso deductivo. Necesitándose justificaciones de segundo nivel, decidir un caso difícil en base a una justificación de primer nivel es abusar de la deducción. La decisión descansaría en un razonamiento formalista, una degeneración del pensamiento formal. El formalismo es el error de no darse cuenta que la decisión necesita de justificaciones de segundo nivel. Es el caso del juez que ignora que está ante una laguna y que le corresponde su integración, o que ignora que está ante una antinomia y que su decisión debe eliminarla. Como efecto, el formalismo corre en contra de la aceptación racional de la decisión. Y, al contrario, decidir un caso fácil en base a una justificación de segundo nivel es caer en un error sustantivo. Éste es una degeneración del pensamiento sustantivo (material). El error consiste en no darse cuenta que el razonamiento deductivo es suficiente para justificar la decisión ${ }^{4}$.

5. Para MacCormick ${ }^{5}$ los criterios de razonabilidad para la construcción de justificaciones de segundo nivel son tres.

a) La universalidad, que no es nueva en el pensamiento jurídico: donde hay identidad de razón debe haber identidad de derecho (ubi eadem ratio iuris, ibi eadem legis dispositio). Supone dar el mismo tratamiento a todos los casos cuyas premisas sean las mismas, y tratar de modo distinto a los que tengan premisas diferentes. Implícitamente, este es el razonamiento que ha llevado al Tribunal Constitucional a afirmar la obligación de una "protección constitucional reforzada de los derechos de las personas pertenecientes

${ }^{4}$ Las definiciones de formalismo y sustantivismo son de Atiy ah, P. S. - Summers, Robert S., Forn and Substance in Anglo-American Law (Nueva York, Clarendon Press, 1987), p. 28.

${ }^{5}$ Cf. MacCormick, Neil, Legal Reasoning and Legal Theory (Nueva York, Clarendon Press, 1978). En la bibliografía nacional puede consultarse Talavera, Pedro; Interpretación, integración y argumentación jurídica (Santa Cruz, El País, 2008), pp. 205-269. 
a sectores en condiciones de vulnerabilidad" (sentencia 846/2012-AAC, 20 de agosto, párrafo III.1). La universalidad de una decisión descansa, a su vez, en una decisión previa: la determinación de las premisas relevantes del caso y la determinación de las premisas relevantes de los casos con los que será confrontado.

b) La coherencia, que i) cuando se refiere a las premisas normativas significa que la justificación no es antinómica con las normas del sistema jurídico, o inconsistente con los valores implícitos que lo unifican. Consecuencia práctica inmediata de esto es la revisión de la legalidad ordinaria en vía de amparo, cuando la "labor interpretativa resultare insuficientemente motivada, arbitraria, incongruente, absurda e ilógica o con error evidente" (sentencia 832/2012-AAC, 20 de agosto, párrafo III.4). ii) Cuando se refiere a las premisas fácticas, la coherencia significa que la prueba y calificación de los hechos debe estar en conformidad con las leyes científicas aplicables y con los datos convencionalmente aceptados por la experiencia. Acá, la consecuencia práctica inmediata es la revisión constitucional de la valoración de la prueba, cuando "exista apartamiento de los marcos legales de razonabilidad y equidad previsibles para decidir" (sentencia 832/2012-AAC, 20 de agosto, párrafo III.5).

c) Y la consecuencia, que conlleva considerar las consecuencias de la decisión según los valores adoptados por el sistema jurídico. La decisión cuyas consecuencias mejor sirvan a estos valores estará mejor justificada. Su fuerza justificativa está en relación directa con los objetivos sociales que persigue el sistema. Por tanto, las justificaciones de consecuencia son adecuadas si contribuyen con tales objetivos. Ya esto ha venido haciéndose cerca de una década atrás, desde que el Tribunal Constitucional explicitó la aplicación directa de los principios y valores superiores del ordenamiento (sentencia 1846/2004RAC, 30 de noviembre, párrafo III.2). Este ha sido el razonamiento, por ejemplo, detrás de la decisión de permitir que en los supuestos de tutela por medidas de hecho se flexibilicen las reglas de legitimación pasiva, cuando quien acude en amparo no pueda identificar a sus demandados (sentencia 1478/2012-AAC, 24 de septiembre, párrafo III.1.2). De no permitirse esta excepción, el ordenamiento estaría trabajando a favor de su propia ruptura, premiando con la imposibilidad de ser demandado a quien lo quebranta por un acto de fuerza patente, beneficiándolo así con su propio ilícito.

6. Hasta aquí la jurisprudencia en materia de argumentación. A partir de ella, dos cosas pueden decirse respecto a la justificación de las decisiones judiciales en la jurisdicción constitucional: $i$ ) el Tribunal Constitucional arrastra una consolidada tradición garantista respecto a que la justificación de las decisiones judiciales enraíza en el derecho a la tutela judicial efectiva y en la garantía del debido proceso; y ii) tal tradición va a la par, cuando menos, 
de las opiniones doctrinales comúnmente aceptadas en la materia. Esta es la altura de la valla que el propio Tribunal ha erigido. Contra ella tiene que medirse la justificación de su sentencia 2471/2012-RDN.

\section{INCUMPLIMIENTO DE LA JURISPRUDENCIA APLICABLE A LOS PRESUPUESTOS PROCESALES DEL RECURSO DIRECTO DE NULIDAD}

\section{Naturaleza directa del recurso directo de nulidad.}

a) El recurso directo de nulidad es, por definición, directo. Su entidad procesal quedó definida por el AC 426/2001-CA (1 de noviembre), que dijo que el recurso directo de nulidad sólo procedía para "aquellos supuestos en los que no es posible obtener la reparación del agravio por no prever el orden legal otro medio de impugnación". Desde que es tal (directo), el recurso directo de nulidad no supone el agotamiento de ninguna vía procesal previa (subsidiaridad), habida cuenta que sólo procede ante la falta de previsión de vías por parte del sistema jurídico. A contrario, de haber una vía que remedie la garantía de competencia, ésta excluye la procedencia del recurso. Esto ha sido recientemente reiterado por el Tribunal Constitucional, a propósito de reencausar un precedente suyo en el que había equiparado la naturaleza directa del recurso en comento con el carácter subsidiario de la acción de amparo constitucional' . Al corregir el equívoco, el Tribunal dijo: "el recurso directo de nulidad, no se rige por el principio de subsidiariedad por lo que a diferencia de la acción de amparo constitucional y conforme se extrae de su propia denominación para su planteamiento no requiere agotar las instancias intra-procesales pero a la vez este recurso, no puede ser sustitutivo de los recursos intra-procesales ordinarios" (sentencia 693/2012-AAC, 2 de agosto, párrafo III.2). Esto no quiere decir que en estos casos la garantía de competencia no pueda ser amparada por la jurisdicción constitucional. Todo lo que quiere decir es que no puede serlo por la vía del recurso directo de nulidad. Para los casos en los que la garantía de competencia tiene remedios previstos en el ordenamiento, su agotamiento es condición para el ejercicio de la acción de amparo: un remedio procesal distinto al recurso directo de nulidad, que no tutela la garantía de competencia en sí misma, sino que repara los daños que la actuación incompetente hubiese generado en los derechos de orden constitucional. Para el caso del arbitraje, el ordenamiento ordinario ha dispuesto mecanismos de salvaguarda de la garantía de competencia, que, por consecuencia, son excluyentes del recurso directo de nulidad. Tal es el caso

${ }^{6}$ Se trata de la sentencia 99/2010-RAC (10 de mayo), que dijo: “[para la procedencia del recurso directo de nulidad] se deben agotar previamente los mecanismos internos efectivos para la restitución de la garantía de competencia" (párrafo III.7). 
de la excepción de incompetencia por: $i$ ) inexistencia de materia arbitrable; ii) inexistencia del convenio arbitral; iii) nulidad del convenio; iv) caducidad del mismo; y $v$ ) exceso en el mandato del tribunal arbitral (artículo 33 de la Ley de arbitraje y conciliación). Y es el caso del recurso de anulación contra el laudo por $i$ ) pronunciarse sobre materia no arbitrable; ii) existencia de casos de nulidad o anulabilidad del convenio arbitral; iii) referencia a controversias no previstas en el convenio arbitral o resueltas en exceso del mismo; y iv) emisión del laudo fuera de plazo (artículos 63.I.1, 63.II.1, 63.II.4 y 63.II.7 de la Ley de arbitraje y conciliación). En todos estos supuestos la razón de la pretensión para accionar el medio de defensa específico es la misma: la actuación sin competencia del tribunal arbitral. Todo lo que varía en cada uno de ellos es la causa de dicha incompetencia, que es lo que da a cada supuesto su autonomía normativa (vg. incompetencia por inexistencia de materia arbitrable, incompetencia por nulidad del convenio, o incompetencia por laudo fuera de plazo). Por tanto, si lo que se quiere es accionar contra un laudo en la jurisdicción constitucional por haber violentado la garantía de competencia, deberá hacérselo a través de la acción de amparo, pidiendo que se repare el daño que la actuación incompetente produjo en los derechos de orden constitucional (que para el caso será la garantía al debido proceso), y previo ejercicio de la excepción dicha y del correlativo recurso de anulación, cuya causal deberá guardar identidad con el supuesto alegado para excepcionar incompetencia. Pero la vía no es el recurso directo de nulidad, que queda de inicio excluida al haber en el ordenamiento que gobierna el arbitraje medios previstos para tutelar la garantía de competencia.

\section{Competencias materia del recurso del directo de nulidad.}

a) Acordemos lo siguiente: competencia y capacidad tienen el mismo significado, pero ámbitos distintos de aplicación. Ambos significan una habilitación del sistema jurídico para hacer algo, un poder. Son el contenido específico de una regla secundaria, que autoriza a introducir, modificar o aplicar el derecho vigente ("power conferring rules"). Quienes están habilitados para hacer esto tienen poderes normativos. En el derecho privado los poderes normativos se denominan capacidad; en el derecho público, competencia ${ }^{7}$. Las cosas por su naturaleza: un tribunal arbitral no es un poder constituido, por tanto, la habilitación normativa que recibe de la Ley de arbitraje y conciliación con el nombre de competencia es por su entidad una capacidad, la capacidad de arbitramento, que es tal porque se desenvuelve en el ámbito del derecho privado, como consecuencia del derecho a arbitrar. Ahora esto:

${ }^{7}$ Cf. HART, H. L. A., The Concept of Law (2a edición, Nueva York, Clarendon Press, 1994), p. 81. 
el recurso directo de nulidad está para guardar las competencias de fuente constitucional (no legal) de los poderes constituidos: "ha de entenderse que el recurso directo de nulidad tiene como finalidad declarar la invalidez de aquellos actos de cualquierpersona o autoridad que usurpe funciones que se arroga sin que la Constitución Politica del Estado le confiera tal autoridad. En ese contexto, son funciones del Estado, primero, aquellas que son propias de los órganos del poder público como las de juzgar (Órgano Judicial), Legislar (Órgano Legislativo) o administrar (Órganos Ejecutivo y Electoral); segundo, los que fungen, conforme prevé el art. 12.II de la CPE, las funciones de control (Contraloria), defensa de la sociedad (Ministerio Público y Defensoría del Pueblo) o defensa del Estado (Procuraduria), y finalmente, tercero, otros órganos a los que la Norma Suprema expresamente les asigna determinadas funciones" (sentencia 265/2012-RDN, 4 de junio, párrafo III.2). Hasta aquí bien, porque el recurso directo de nulidad es un medio de defensa de la Constitución, no de la legalidad ordinaria. Pero este es el problema: el hecho de dictar un laudo no es materia del recurso directo de nulidad, porque $i$ ) no es producido por un órgano constitucional en cumplimiento de una competencia pública nacida de la Constitución, sino que ii) es producido por particulares en ejercicio de una capacidad delegada por el derecho a arbitrar que ostentan las partes. Acá debe distinguirse el derecho a arbitrar, del que deriva la capacidad de arbitramento (derecho privado), del poder de jurisdicción, que corresponde al Poder Judicial (derecho público).

b) El arbitraje es un derecho, no una competencia pública, y es de fuente constitucional, porque deriva de la propiedad privada (artículo 56 de la Constitución). Deducir un derecho en la vía arbitral es en naturaleza jurídica un acto de disposición. Cuando la Constitución garantiza la propiedad, garantiza sus facultades, esto es, la posibilidad de usar, gozar y disponer de un derecho de contenido patrimonial. Como siendo propietario se puede disponer de un derecho, al garantizar la propiedad se está garantizando también la libertad de contratación, como medio para ejercer dicho poder de disposición. Por tanto, derechos tales como vender, comprar o donar, que tienen todos su fuente en un contrato, enraízan en la Constitución, porque todos derivan de un acto de disposición comprendido en las facultades de la propiedad, instrumentalizado, en el caso de los ejemplos, a través de un acto jurídico. Y lo mismo ocurre con el arbitraje. Que se pacte someter a la decisión de un tercero una controversia de carácter patrimonial es tan sólo hacer ejercicio de la facultad de disposición que corresponde a los titulares de los derechos envueltos en tal controversia. Por eso que la Ley de arbitraje y conciliación diga que son arbitrables las controversias de las partes "mediante el ejercicio de su libre arbitrio sobre derechos disponibles" (artículo 3), porque la decisión de pactar el arbitraje sólo puede corresponder a las partes y porque dicho 
pacto sólo puede hacerse sobre un derecho respecto al cual tengan poder de disposición. Ergo, habiendo propiedad, hay arbitraje. Llevado al derecho procesal, en el derecho de propiedad enraíza el principio dispositivo, que define al proceso civil por oposición al proceso penal, regido por el principio de necesidad. Según el principio dispositivo, corresponde únicamente a las partes iniciar el proceso y ponerle fin, y definir su contenido y los alcances de la tutela solicitada. "Como decía Calamandrei, el deducir un derecho en vía jurisdiccional es un modo de disponer del mismo y, por consiguiente, el condicionar la tutela jurisdiccional a la petición del interesado es una consecuencia lógica de la autonomía negocial reconocida al particular sobre su

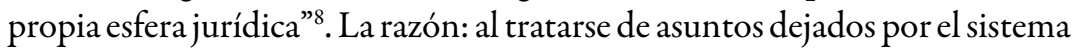
jurídico a la libre disponibilidad de los particulares, sólo a ellos corresponde la decisión sobre la suerte de sus propios derechos. Como el arbitraje comparte con el proceso civil esa misma racionalidad, no sólo que su ejercicio derive del artículo 56 de la Constitución, sino que, una vez que las partes deciden ejercer su derecho a someterse a arbitramento, la habilitación a los árbitros nace también de ese mismo artículo (su capacidad de arbitramento), porque los árbitros sólo pueden decidir sobre aquello que ellas dispusieron someter a su juicio.

c) Pero una cosa es capacidad de arbitramento y otra poder de jurisdicción. Ambas juzgan, pero sus respectivas entidades quedan definidas por la distinta fuente de la que cada una obtiene su habilitación para juzgar. $Y$ es que mientras la capacidad de arbitramento deriva de la libertad de disposición y supone, como tal, la práctica de un derecho, sólo el poder de jurisdicción deriva de la soberanía popular y supone, como tal, el cumplimiento de una competencia pública. Se trata de la unidad jurisdiccional, que la hay cuando la justicia que emana del pueblo (artículo 178.I) sólo la ejerce el Poder Judicial (artículo 179.I). Dice de su encargo soberano a un solo órgano, por oposición a los poderes Ejecutivo y Legislativo. Arraiga en la división de poderes, porque es consecuencia de la prohibición de delegación de las competencias públicas (artículo 12.III), y su consecuencia obvia es la prohibición de tribunales de excepción (como organización, artículo 180.III; como derecho, artículo 120.I). Como el Poder Judicial está formado por una pluralidad de órganos independientes entre sí (jueces y tribunales), todos ellos forman una unidad si sus decisiones son revisables, directa o indirectamente, por un único órgano supremo. Y como todo acto de aplicación del derecho está sujeto a las garantías constitucionales, el órgano que da unidad al Poder Judicial es el Tribunal Constitucional, encargado de su tutela (artículo 196.I). Aplicado al arbitraje,

${ }^{8}$ Montero Aroca, Juan, Losprincipios politicos de la nueva Ley de Enjuiciamiento Civil (Valencia, Tirant Lo Blanch, 2001), p. 64. 
la unidad jurisdiccional significa la competencia que tiene el Poder Judicial para enjuiciar la validez de las decisiones arbitrales. Pero esto va al margen de la capacidad de arbitramento. Los árbitros no juzgan por delegación de la soberanía popular (artículo 7), sino por mandato de la voluntad de las partes, que en ejercicio de su libertad de actuación disponen de sus derechos, encargando la resolución de sus controversias a un tercero. Esto es consecuencia de su propia naturaleza privada, derivada de la libertad de disposición como facultad aneja al derecho de propiedad. Este es el razonamiento implícito en esta afirmación del Tribunal Constitucional, que de otra forma no podría entenderse: "los tribunales arbitrales [...] responden a la voluntad de las partes" (sentencia 17/2001-RAC, 19 de marzo, párrafo IV.5). Consecuencia de que la capacidad de arbitramento derive de la libertad de disposición es la relación que los árbitros mantienen con las partes: "Para que se cumpla con el objeto del arbitraje [...], se hace necesario el árbitro. Y al árbitro, obviamente, hay que contratarlo. Ese contrato entre quien arbitrará y quienes están obligados a que una controversia sea arbitrada, es un contrato de locación de servicios. Queda celebrado el contrato de locación de servicios cuyo objeto es en este caso la prestación de un servicio de arbitraje, cuando el designado por las partes, ya sea directamente o a través de un mecanismo establecido en la cláusula arbitral, acepta prestar ese servicio personalísimo" 9 . La diferencia de concepto en la relación del árbitro con las partes y la de los jueces con los litigantes es consecuencia de la fuente de la cual derivan sus respectivas habilitaciones para juzgar. En esta última existe una relación de derecho público, nacida directamente de la soberanía popular, cuya traducción llana en términos operativos es que los jueces no necesitan ser nombrados por las partes en litigio. En cambio, como la capacidad de los árbitros para resolver una controversia no deriva de la soberanía popular, sin nombramiento de las partes carecen de título que los habilite para conocer la controversia. Pero de espaldas a todo esto está sentencia 2471/2012-RDN. Para entenderla, habría que asumir que capacidad de arbitramento y poder de jurisdicción son lo mismo (i.e. que los árbitros son un órgano constitucional que juzga por delegación de la soberanía popular). Una de dos: ó se acepta esto como consecuencia de la sentencia 2471/2012-RDN, ó se acepta que ella rehuyó la aplicación del precedente reglado en la sentencia 265/2012-RDN.

\section{Legitimación activa de la Procuraduria General del Estado en sede} constitucional.

a) Ya el Tribunal Constitucional había distinguido la participación de

\footnotetext{
${ }^{9}$ Castillo Freyre, Mario - Vásquez Kunze, Ricardo, Arbitraje: El juicio privado (Lima, Palestra, 2007), pp. 63-64.
} 
la Procuraduría General del Estado en la jurisdicción constitucional según las competencias constitucionales que ejerciese. Al efecto, distinguió entre su competencia para ejercer la representación del Estado y su competencia para supervisar a las unidades jurídicas de la Administración Pública. En el caso de la primera, la Procuraduría puede actuar directamente como parte en representación del Estado. Pero no ocurre lo mismo con la segunda. Acá, "cuando sean las entidades públicas las que ejerzan directamente la representación de las entidades públicas y por ende sean éstas parte procesal en causas jurisdiccionales o administrativas, el rol de la Procuraduría General del Estado, será el de supervisar a las unidades jurídicas de la administración pública en cuanto a su actuación procesal" (sentencia 353/2012-AAC, 22 de junio, párrafo III.1).Y aquí viene la contradicción: en el caso del arbitraje cuyo laudo fue luego sometido al recurso directo de nulidad, no fue la Procuraduría quien asumió la defensa en sede arbitral, sino la propia empresa pública demandada. En consecuencia, a la Procuraduría le correspondía únicamente ejercer su tarea supervisora sobre la unidad jurídica de dicha empresa, pero no asumir la representación procesal del Estado en la jurisdicción constitucional.

4. Norma aplicable en el tiempo para computar el plazo para ejercer el derecho de acción.

a) El laudo era de 21 de enero de 2008 y el recurso directo de nulidad de 3 de agosto de 2012. Entre ambos mediaron 44 meses. En ese mismo período se sucedieron tres leyes en la materia: $i$ ) la Ley del Tribunal Constitucional, de 1 de abril de 1998, que daba 30 días para el ejercicio del recurso directo de nulidad (artículo 81) y que mantuvo su vigor hasta el "primer día hábil del año 2011", de acuerdo a la "Disposición Abrogatoria" de la Ley del Tribunal Constitucional Plurinacional; ii) la Ley del Tribunal Constitucional Plurinacional, que extendía dicho plazo a seis meses (artículo 159), y que entró en vigor en su integridad el 2 de enero de 2012, al posesionarse a los nuevos magistrados constitucionales, de acuerdo a su "Disposición Transitoria Segunda"; y iii) el Código Procesal Constitucional, de 5 de julio de 2012, pero en vigor recién desde el 6 de agosto del mismo año ("Disposición Transitoria Primera"), a partir de cuyo silencio al respecto se interpreta que el recurso se puede presentar en cualquier tiempo (i.e. el paso del tiempo ya no opera como una condición convalidatoria de la invalidez del acto producido ultra vires). Este es un conflicto de normas en el tiempo. El problema: cuál de estas leyes es la aplicable: $i$ ) ¿la Ley vigente a la fecha del laudo?, que si fuera así sería la Ley del Tribunal Constitucional; ii) ¿la Ley vigente a la fecha de presentación del recurso?, que para el caso sería la Ley del Tribunal Constitucional Plurinacional; ó iii) ¿la Ley vigente después de la presentación del recurso pero anterior a su resolución?, que para el caso sería el Código 
Procesal Constitucional. Tanto la mayoría como la disidencia aplicaron la Ley vigente a la fecha de presentación del recurso (i.e. la Ley del Tribunal Constitucional Plurinacional). Y aquí está la contradicción: debieron aplicar la Ley vigente a la fecha del laudo (i.e. la Ley del Tribunal Constitucional). La razón: a eso lleva la jurisprudencia constitucional sobre irretroactividad.

b) El artículo 123 de la Constitución norma que i) "la ley sólo dispone para lo venidero y no tendrá efecto retroactivo" (regla general), excepto ii) "en materia laboral, cuando lo determine expresamente a favor de los trabajadores", iii) "en materia penal, cuando beneficie al imputado" (favor $r e i)$, y iv) "en materia de corrupción, para investigar, procesar y sancionar los delitos cometidos por servidores públicos contra los intereses del Estado" (esta última excepción es inaplicable por contraria al favor rei, de acuerdo a la sentencia 770/2012-AIC, 13 de agosto, párrafo III.4.1). La garantía de irretroactividad es una regla para la resolución de los conflictos de normas en el tiempo. Estos conflictos se resuelven por la aplicación irretroactiva, ultraactiva o retroactiva de las normas.i) La irretroactividad supone la aplicación inmediata de una norma, que es "inmediata" porque se aplica a los hechos, situaciones o relaciones que ocurren mientras tiene vigencia: desde su entrada en vigor hasta su derogación. ii) La ultraactividad supone la aplicación de una norma a los hechos, situaciones o relaciones que ocurren luego de que ha sido derogada: después de finalizada su aplicación inmediata. iii) Y la retroactividad supone la aplicación de una norma a hechos, situaciones o relaciones pasadas, que acaecieron antes de que la norma entrase en vigor: antes de su aplicación inmediata.

c) Llegados acá, lo que la Constitución prohíbe es la retroactividad (la ley "no tendrá efecto retroactivo", artículo 123), y la determinación del carácter retroactivo de una norma se resuelve alternativamente a partir de una de las dos soluciones teóricas siguientes.

i) La teoría de los derechos adquiridos, que sostiene que una vez que un derecho ha nacido y se ha consolidado para un sujeto, las normas posteriores no pueden modificarlo. "En consecuencia, el derecho seguirá produciendo los efectos previstos al momento de su constitución, bien por el acto jurídico que le dio origen, bien por la legislación vigente cuando tal derecho quedó establecido". "Tiende a conservar las situaciones existentes y rechaza la modificación de las circunstancias por las nuevas disposiciones legales". La teoría "diferencia entre derechos adquiridos, facultades y expectativas. Las facultades son atribuciones genéricas para actuar de acuerdo con el derecho y, en tanto tales, no son derechos y no pueden ser adquiridas". "De otro lado, las expectativas son previsiones no protegidas jurídicamente de que yo pueda, 
eventualmente, llegar a tener tal bien o cosa"10. Ejemplo de la aplicación de esta teoría es el asunto "Lochner v. New York" (1905), en el que la Corte Suprema de Estados Unidos declaró que una ley del Estado de Nueva York imponiendo una jornada laboral de ocho horas para los panaderos era inconstitucional por violar la libertad contractual, ya que los contratos entre los patrones y los panaderos debían regirse hasta su terminación por la ley vigente a tiempo de su celebración.

ii) La teoría de los hechos cumplidos, que sostiene que cada norma jurídica debe aplicarse a los hechos que ocurran durante su vigencia (aplicación inmediata). "Si se genera un derecho bajo una primera ley y luego de producir cierto número de efectos esa ley es modificada por una segunda, a partir de la vigencia de esta nueva ley, los nuevos efectos del derecho se deben adecuar a esta y ya no ser regidos más por la norma anterior bajo cuya vigencia fue establecido el derecho de que se trate. Es una teoría que privilegia la transformación del Derecho a impulso del legislador"11.

d) Hasta acá la doctrina, ahora el derecho positivo. Desde la introducción en el texto de la Constitución de la garantía de irretroactividad de la ley en las reformas de $1846^{12}$ hasta el presente, la Constitución jamás ha determinado ella misma el significado jurídico de dicha garantía: no ha tomado partido por la teoría de los derechos adquiridos ni por la teoría de los hechos cumplidos. Por tanto, en su condición de intérprete final de la Constitución, tal determinación normativa corresponde al Tribunal Constitucional. Y éste lo ha venido haciendo, tomando partido por la teoría de los hechos cumplidos desde su primera sentencia en la materia: "se entiende por retroactividad no auténtica conocida también como retrospectividad cuando una ley regula o interviene en situaciones fácticas aún no concluidas" (sentencia 11/2001-RII, 5 de febrero, párrafo VI.1) ${ }^{13}$. Al decir esto, la

${ }^{10}$ Rubio Correa, Marcial; Aplicación de la norma jurídica en el tiempo (Lima, PUCP, 2007), p. 27.

${ }^{11}$ Ibíd., p. 28.

${ }^{12}$ Artículo 89 de la Constitución reformada en 1843: "Ninguna ley puede tener fuerza retroactiva".

${ }^{13}$ Tal vez los casos políticamente más connotados de aplicación de este precedente fueron los dos siguientes: i) El asunto de la reforma del artículo 93. III de la Constitución (texto de 1967), acusándose que su aplicación a la convocatoria de elecciones generales de 2005 sería retroactiva por acortar el período para el que fueron electos los miembros del Congreso, el Tribunal resolvió que la aplicación inmediata del artículo reformado era irretroactiva. Si acá aplicaba la teoría de los derechos adquiridos, hubiese resuelto que el período de funciones de los parlamentarios no podía acortarse (sentencia 76/2005-RDI, 13 de octubre, párrafo III.3). ii) Y el caso de la obligación de migrar a un nuevo régimen legal que impuso la Ley de Hidrocarburos de 2005, al derogar a la ley que la precedía en la materia. También acá, el Tribunal sostuvo que tal obligación era 
jurisprudencia constitucional está diciendo que es retroactiva toda norma que regule hechos, relaciones o situaciones cuyas consecuencias jurídicas ya se produjeron (hechos cumplidos). Es seña manifiesta de afincamiento de la teoría de los hechos cumplidos en el pensamiento constitucional boliviano la siguiente afirmación de la jurisprudencia, producida a la década de iniciada la línea en comento: "el principio de irretroactividad no se contrapone con la necesidad de mutaciones normativas, que impiden la petrificación de un orden jurídico que ha de ser dinámico, en el sentido de ajustar a las condiciones y circunstancias actuales, sin que esto implique el desconocimiento de situaciones jurídicas definidas de acuerdo con la ley, ni la vulneración de los derechos adquiridos" (sentencia 1045/2011-RAC, 29 de junio, párrafo III.2; y también en sentencia 770/2012-AIC, 13 de agosto, párrafo III.3). Por consiguiente, todo cambio legislativo ("mutaciones" como las llama la jurisprudencia citada) que alcance a las consecuencias jurídicas no cumplidas de un hecho, relación o situación es irretroactivo. Y, a la inversa, todo cambio legislativo que alcance a las consecuencias jurídicas ya cumplidas de un hecho, relación o situación será retroactivo. Así planteadas las cosas, conocido el laudo arbitral, éste comenzó a producir efectos jurídicos. Uno de éstos es que su notificación echó a andar los plazos previstos para su impugnación. Vencidos estos plazos, por su entidad procesal, los mismos quedaron caducos. Es decir, que la consecuencia del paso del tiempo quedó cumplida, haciendo que los medios impugnatorios cuyos plazos de interposición caducaron ya no pudiesen ser ejercidos. Como el laudo era de 21 de enero de 2008, la ley aplicable era la Ley del Tribunal Constitucional, porque era la única ley vigente en la materia a ese tiempo. Como esta Ley establecía un plazo de 30 días para la presentación del recurso directo de nulidad, transcurridos los mismos, el ejercicio del recurso quedó excluido, por caducidad del plazo para su interposición.

\section{INCUMPLIMIENTO DE LA JURISPRUDENCIA SOBRE ARBITRAJE}

\section{Reconstrucción del concepto jurisprudencial de orden público.}

a) El Tribunal Constitucional jamás ha elaborado expresamente sobre el concepto de orden público, así que, en justicia, es imposible refutarle lo que no ha hablado. Y esto es lo reprochable: ya que el fundamento para declarar la nulidad del laudo de 21 de enero de 2008 fue que el mismo era violatorio del orden público, desde el punto de vista de la justificación de

irretroactiva. Y, también acá, si el Tribunal hubiese razonado a partir de la teoría de los derechos adquiridos, habría tenido que concluir que la nueva regulación no podía ser aplicable a los titulares de contratos de riesgo compartido celebrados al amparo de la anterior Ley (sentencia 45/2006-RDI, 2 de junio, párrafo I.1). 
las decisiones judiciales, era necesario que la sentencia 2471/2012-RDN comenzase por definirlo. A pesar del silencio al respecto, por comparación, es posible reconstruir una definición jurisprudencial de orden público a partir del concepto que del mismo maneja la jurisprudencia extranjera. Es decir, a pesar de no haberse referido a él expresamente, el Tribunal Constitucional sí se ha referido al mismo contenido que en la jurisprudencia comparada se denomina orden público. Que no le haya dado el nombre es cosa que no afecta a su entidad jurídica, pero que sí lo exime de reprochársele una contradicción directa, frontal, a su propia jurisprudencia, con la salvedad dicha por callar respecto a su formulación.

b) En la jurisprudencia extranjera el orden público es un concepto de principio. Como tal, es de formulación abstracta, pero de aplicación restrictiva (i.e. no todo hecho repudiable es una violación de principio). En el caso estadounidense, por ejemplo, el orden público se contrae a "las nociones más básicas de moralidad y justicia" (Corte de Apelaciones del Segundo Circuito de Estados Unidos, asunto "Parsons \& Whittemore Overseas Co. v. Société Générale de l'Industrie du Papier", de 1974) ${ }^{14}$. El mismo criterio, incluyendo el lenguaje empleado en su formulación, se usa en Hong Kong (Corte Superior de la Región Administrativa Especial de Hong Kong, asunto "Hebei Import and Export Corporation v. Polytek Engineering Company Ltd", de 1998) $)^{15}$ e Irlanda (Corte Superior de Irlanda, asunto "Brostom Tankers AB v. Factorías Vulcano SA", de 2004) ${ }^{16}$. Lo mismo que en Alemania y Suiza, donde no toda violación al derecho encarna una violación al orden público, excepto, respectivamente, cuando se infringe "una norma que regula los principios básicos de la vida pública o económica o cuando tal infracción contradice de un modo intolerable el concepto alemán de justicia", o cuando "el sentimiento innato de justicia es lastimado de modo intolerable al inaplicarse una disposición fundamental del sistema jurídico suizo" ${ }^{17}$. Igual es el caso noruego, en el que hay violación al orden público "únicamente cuando [el laudo] discrepa en grado inaceptable con el orden jurídico del Estado, violando un principio fundamental del mismo" ("Pulsarr Industrial Research BV v. Nils H. Pilsen AS”, de 2002) ${ }^{18}$. O en Canadá,

${ }^{14}$ Disponible en https://bulk.resource.org/courts.gov/c/F2/508/508.F2d.969.741676.74-1642.174.637.html

${ }^{15}$ Disponible en http://arbitrationlaw.com/files/free_pdfs/hebei_import_and_ export_corp_v_polytek_engineering_co_ltd_cacv_116-1997.pdf

${ }^{16}$ Disponible en http://www.bailii.org/ie/cases/IEHC/2004/198.html

${ }^{17}$ En Ungar, Kenneth, The Enforcement of Arbitral Awards Under UNCITRAL's Model Law on International Commercial Arbitration, en Columbia Journal of Transnational Law, 25 (1987), p. 751.

${ }^{18}$ En Born, Gary, International Commercial Arbitration: Commentary and Materials (2a edición, La Haya, Kluwer, 2001), p. 740. 
donde una violación al orden público es tal por ser "contraria a la moralidad esencial del Estado" (Corte de Ontario, Canadá, asunto "Arcata Graphics Buffalo Ltd. v. Movie-Magazine Corp.”, de 1993) ${ }^{19}$. Y en España, país en el que se denomina orden público constitucional al régimen compuesto por los derechos y libertades fundamentales reconocidos en su Constitución ${ }^{20}$.

c) Reconstruido a partir de la jurisprudencia comparada, el concepto de orden público se refiere al fundamento ético del sistema jurídico del Estado en cuestión: es el sustento moral de la filosofía política que lo determina. Aunque lingüísticamente abstracto, su significado jurídico puede ser objeto de determinación, aunque con el margen de vaguedad propio de los conceptos indeterminados. Tratándose de Estados de cuño liberal, su fundamento ético es la libertad individual ${ }^{21}$. Y para que ésta quede asegurada tiene que asegurarse la existencia del Estado en la acepción garantista del término ${ }^{22}$. Esto es, como un gobierno de poderes limitados, cuyas competencias se organizan en la forma frenos y contrapesos. Ya sobre esto ha dicho el Tribunal Constitucional que "el Estado de Derecho [se] caracteriza por la sujeción de los poderes públicos y los ciudadanos al ordenamiento jurídico vigente, $[\mathrm{y}]$ por su vinculación a un ordenamiento superior en que se consagran y garantizan unos valores (derechosy libertades) que, desde el punto de vista moraly politico, se consideran básicos para la convivencia humana y la consecución de la paz social" (sentencia 101/2004 RAC, 14 de septiembre, párrafo III.2). Hasta aquí queda que el orden público común a toda república estaría compuesto por $i$ ) las libertades constitucionales; $\mathrm{y} i$ ) el sistema de frenos y contrapesos. A esto, para el caso boliviano en específico, debiera añadirse iii) su "carácter plurinacional", que ha sido definido como el "hecho fundante básico del Es-

\footnotetext{
${ }^{19}$ Disponible en http://interarb.com/clout/clout037.htm

${ }^{20}$ Cf. Fernández Rozas, José Carlos - Sánchez Lorenzo, Sixto, Derecho Internacional Privado (2a edición, Madrid, Civitas, 2003), p. 314.

${ }^{21}$ En esto lleva la razón Popper, Karl R., La responsabilidad de vivir. Escritos sobre politica, historia y conocimiento (Barcelona, Paidós, 1995), pp. 147 y 236: "No escogemos la libertad política porque nos prometa esto o aquello. La escogemos porque hace posible la única forma de convivencia entre individuos digna de un ser humano; la única forma en la que podemos ser completamente responsables por nosotros mismos". "La libertad política es una condición previa de nuestra responsabilidad personal, de nuestra humanidad".

${ }^{22} \mathrm{Y}$ en esto tiene razón SARTori, Giovanni; ¿Qué es la democracia? (Madrid, Taurus, 2003), pp. 276 y 277): “[Que] el Estado constitucional haya sido concebido en los tiempos del Estado pequeño y como un Estado que 'nada hace' (el Estado como perro guardián), nada prohíbe que se transforme, si es necesario, en un Estado grande que 'hace mucho', con esta condición esenciadísima: cuanto más deja de ser un Estado mínimo, tanto más importante que permanezca como Estado constitucional, en la acepción garantista del término".
} 
tado y de la Constitución boliviana" (sentencia 112/2012 RHC, 27 de abril, párrafo III.1.2). Contrastado lo dicho con la sentencia 2471/2012-RDN, no parece que encargar a un tribunal arbitral declarar la nulidad de un acto jurídico atente contra el fundamento político y moral del Estado boliviano. Al menos prima facie no parece disolver su "hecho fundante básico", que para el caso nacional es el equivalente jurisprudencial a "las nociones más básicas de moralidad y justicia" referido por la jurisprudencia comparada.

2. Licitud de someter a arbitramento pretensiones de nulidad contractual.

a) Al decir que "la nulidad y la anulabilidad de un contrato deben ser pronunciadas judicialmente", el artículo 546 del Código Civil está diciendo dos cosas: $i$ ) se está refiriendo a la presunción de validez que acompaña a todo el proceso de producción jurídica; y ii) está habilitando a los jueces para declarar vencida dicha presunción (i.e. declarar la invalidez de los actos jurídicos). Toda la producción jurídica se rige por la presunción de validez: las normas son válidas hasta que el órgano atribuido de competencia por el sistema jurídico no declare su invalidez. Si constitutivamente el sistema jurídico requiere de un acto formal para que una norma comience a existir como derecho, también requiere de una declaratoria formal de invalidez para que una norma cese su existencia jurídica. Validez e invalidez son datos objetivos, consecuentes con el carácter formal del sistema jurídico, no juicios subjetivos a cargo de las partes contratantes. Aplicada al derecho contractual, la presunción de validez opera impidiendo a las partes valerse de la nulidad como argumento eximente de su responsabilidad por incumplimiento, pues, en tanto el acto jurídico no sea declarado formalmente nulo, sus efectos seguirán produciéndose. Hasta aquí el significado jurídico del artículo 546 del Código Civil. Pero, tomado en pareja con el artículo 32.II de la Ley de arbitraje y conciliación, su segundo significado varía. Contrario a lo dicho por el Tribunal Constitucional, no sólo los jueces pueden declarar la nulidad de los actos jurídicos, sino también los árbitros. Al enfrentarse con el artículo 32.II de la Ley de arbitraje y conciliación, el Tribunal Constitucional dijo que éste se refería a nulidades pactadas contractualmente. La vacuidad de este oxímoron ya fue explicada en el párrafo 8.2. Para llegar a tal solución, el Tribunal dijo que hacía una interpretación sistemática entre dicho artículo y el artículo 546 del Código Civil. Y ya que concluyó que por virtud del segundo la declaratoria de nulidad era materia reservada a la jurisdicción ordinaria, habrá que asumir que el Tribunal entiende que, contrariamente al pensamiento jurídico común, i) la norma anterior deroga a la posterior; y $i$ i) la norma general se aplica con preferencia la norma especial. Tal el absurdo sostenido a título de interpretación sistemática. Si la norma que dice "la decisión arbitral que declare la nulidad de un contrato no determinará 
de modo necesario la nulidad del convenio arbitral" (artículo 32.II de la Ley de arbitraje y conciliación) es una norma posterior en el tiempo (1997) y especial por su materia (arbitraje) respecto a la norma general (Código Civil) de 1976 que dice "la nulidad y la anulabilidad de un contrato deben ser pronunciadas judicialmente" (artículo 546 del Código Civil), entonces una de dos: ó se entiende que se está ante una derogación tácita; ó se entiende que se está ante una regulación especial. En ambos casos el resultado el mismo: el significado jurídico del artículo 32.II de la Ley de arbitraje y conciliación es que la declaratoria de nulidad de los actos jurídicos es asunto arbitrable. No otra cosa puede significar decir "la decisión arbitral que declare la nulidad de un contrato".

b) A esta conclusión ya había llegado el propio Tribunal Constitucional una década atrás: "Que las normas impugnadas supuestamente entran en contradicción con el artículo 116-IIy III de la Constitución Política del Estado que dispone que no pueden establecerse tribunales o juzgados de excepción y que la facultad de juzgar en la via ordinaria, contenciosa y contencioso-administrativa y la de hacer ejecutarlojuzgado corresponde a la Corte Suprema y a los tribunales y jueces respectivos, bajo el principio de unidad jurisdiccional, así como con el articulo 30 de la Carta Fundamental que establece que los poderes públicos no podrán delegar las facultades que les confiere esta Constitución y con el artículo 546 del Código Civil que señala que la nulidad y la anulabilidad de los contratos serán pronunciados judicialmente. Que el parágrafo I del artículo 32 de la Ley de arbitraje y conciliación no tiene ninguna relación con las normas constitucionales que supuestamente contradice. Por su parte, el parágrafo II de dicha disposición legal asi como el articulo 12-II y III de la Ley de arbitraje y conciliación, al otorgar la posibilidad de que una decisión arbitral declare la nulidad de un contrato sin que ello determine necesariamente la nulidad del convenio arbitral, asi como al ordenar que la autoridad judicial se inbiba de conocer el caso si estásujeto a convenio arbitral,ó que interpuesta la excepción de arbitraje pueda declararla probada o desestimarla, no conllevan delegación ni desconocimiento de las facultades propias del Poder Judicial ni atentan contra elprincipio de unidad jurisdiccional; por ende, no contradicen los articulos $30 y$ 116-III de la Constitución, ya que la Ley de arbitraje y conciliación establece expresamente las atribuciones del tribunal arbitral, asi como sus limitaciones, detallando en el artículo 6 las materias excluidas de arbitraje, dentro de las que se encuentra la referente a la capacidad de las personas esgrimida en el proceso principal que origina el presente recurso. Que por otra parte, los tribunales arbitrales o de conciliación no constituyen tribunales o juzgados de excepción, al contrario, responden a la voluntad de las partes expresada en un contrato escrito y tienen por objeto llegar a un acuerdo sin necesidad de llegar a los estrados judiciales, constituyéndose en un medio alternativo que contribuye a la 
administración de justicia. Que por otra parte, los tribunales arbitrales tienen plena competencia para declarar la rescisión o nulidad de los contratos que estén sometidos a su conocimiento" (sentencia 17/2001-RII, 19 de marzo, párrafos IV.3 a IV.5). De acuerdo con su propia jurisprudencia sobre producción judicial del Derecho, el Tribunal Constitucional es libre de mutar este precedente si considera que otra interpretación acomoda mejor en el sistema jurídico (i.e. si es más consecuente con el mismo por su universalidad y coherencia). Lo que no es libre de hacer es rehuir silenciosamente sus propios precedentes. Eso es arbitrariedad, y es eso lo que ha ocurrido acá.

\section{BIBLIOGRAFÍA}

Atiyah, P. S. - Summers, Robert S., Forn and Substance in Anglo-American Law (Nueva York, Clarendon Press, 1987).

BecCaria, César; De los delitosy de laspenas (traducción al castellano, Madrid, Aguilar, 1974).

Born, Gary, International Commercial Arbitration: Commentary and Materials (2a edición, La Haya, Kluwer, 2001).

Castillo Freyre, Mario - Vás euez Kunze, Ricardo, Arbitraje: El juicio privado (Lima, Palestra, 2007).

Fernández Rozas, José Carlos - Sánchez Lorenzo, Sixto, Derecho Internacional Privado (2a edición, Madrid, Civitas, 2003).

Hart, H. L. A., The Concept of Law (2a edición, Nueva York, Clarendon Press, 1994). MacCormick, Neil, Legal Reasoning and Legal Theory (Nueva York, Clarendon Press, 1978).

Montero Aroca, Juan, Losprincipiospoliticos de la nueva Ley de Enjuiciamiento Civil (Valencia, Tirant Lo Blanch, 2001).

Popper, Karl R., La responsabilidad de vivir. Escritos sobre politica, historia y conocimiento (Barcelona, Paidós, 1995).

Rubio Correa, Marcial; Aplicación de la norma jurídica en el tiempo (Lima, PUCP, 2007).

SARTORI, Giovanni; ¿Qué es la democracia? (Madrid, Taurus, 2003).

TAlavera, Pedro; Interpretación, integración y argumentación jurídica (Santa Cruz, El País, 2008).

Ungar, Kenneth, The Enforcement of Arbitral Awards Under UNCITRAL's Model Law on International Commercial Arbitration, en Columbia Journal of Transnational Law, 25 (1987). 